Vol. 4, $n^{\circ} 1 \mid 2000$

Varia

\title{
Placing blame : Criminal law and constitutional narratives in revolutionary Boston
}

Steven Wilf

\section{(2) OpenEdition \\ Journals}

Electronic version

URL: https://journals.openedition.org/chs/847

DOI: $10.4000 /$ chs. 847

ISSN: 1663-4837

Publisher

Librairie Droz

Printed version

Date of publication: 1 January 2000

Number of pages: $32-61$

ISBN: 2-600-00433-5

ISSN: 1422-0857

\section{Electronic reference}

Steven Wilf, "Placing blame : Criminal law and constitutional narratives in revolutionary Boston", Crime, Histoire \& Sociétés / Crime, History \& Societies [Online], Vol. 4, $n^{\circ} 1$ | 2000, Online since 02 April 2009 , connection on 23 March 2022. URL: http://journals.openedition.org/chs/847 ; DOI: https://doi.org/ $10.4000 /$ chs. 847 


\title{
Placing blame: \\ Criminal law and constitutional narratives in revolutionary Boston
}

\author{
Steven Wilf ${ }^{1}$
}

\begin{abstract}
How did the American Revolution shape the emergence of a robust, often sophisticated language of law? This essay argues that legal language in the formative era of American law can best be understoot by examining public responses to highly publicized criminal trials. Such an approach marks a significant departure from the received historiography. Most traditional historians have portrayed American resistance to British domination as antinomian, involving largely riots and extra-legal civil disobedience.

This article shows the opposite was the case. Revolutionary Americans were not antinomian, but deeply concerned with legal norms. These legal norms did not await the ratification of the Constitution, but were constructed from the fabric of political, and even ordinary, criminal law cases which became deeply contested causes célèbres. The essay consists of two close readings of inter wining cases that took place in Boston during the 1760s. During the course of these two courtroom trials, a ground-swell of extra-official examinations of these cases-many of them aimed at a popular audienceserved to create a criminal law jurisprudence with a revolutionary cast.
\end{abstract}

De quelle manière la Révolution américaine a-t-elle contribué à l'émergence d'un discours juridique solide et souvent élaboré? Nous considérons que c'est en étudiant les réactions publiques à des procès pénaux à forte visibilité que l'on peut comprendre le discours de la période où le droit américain s'est constitué. Une telle approche s'éloigne nettement de l'historiographie reçue. La plupart des historiens traditionnels ont dépeint la résistance américaine la domination britannique sous la forme principalement d'un rejet des lois, d'émeutes et de désobéissance civile. Cet article montre le contraire, à partir de l'analyse de deux affaires entremêlées, qui se déroulèrent à Boston dans les années 1760. Les révolutionnaires américains ne rejetaient pas les lois et étaient très préoccupés par les normes juridiques. Celles-ci anticipèrent sur la constitution et étaient construites à partir d'affaires pénales ordinaires ou politiques qui devinrent des causes célèbres. Ces deux procès suscitèrent une véritable explosion d'analyses non-officielles visant fréquemment un public populaire - et qui contribuèrent à susciter une jurisprudence pénale de caractère révolutionnaire.

1 Steven Wilf teaches at the University of Connecticut School of Law. He graduated with a J.D. from Yale Law School (1995) and a Ph. D. in History from Yale University (1995). Recently, he has been the Fellow in Comparative Legal History at the University of Chicago and a law clerk in the U.S. Court of Appeals for the Second Circuit. In addition to legal history, Mr. Wilf writes in the field of Intellectual Property. He is currently completing book on the relationship between politics and criminal law in the period of the American Revolution. 
Constitutional scholars and social historians have uncovered two very different languages of law articulated by revolutionary Americans. Constitutional scholars have engaged in an archeological task, recovering a literary discourse about constitutional issues dealing with patriot theories of rights, the relationship between England and the colonies, and the quest for a balanced government. This enterprise, of course, is related to their interest in the historical foundations of American Constitutionalism. On the other hand, historians have been concerned with a quite different legal language, one which seems hardly legal and, at times, hardly a language at all. In fact, historians have often portrayed the relationship of ordinary Americans in the Revolution as antinomian: launching extralegal attacks on British customs officials; engaging in riots and a broad array of civil disobedience meant to shunt aside official legal norms, not to engage with them.

These two approaches - one focused on a learned elite's articulated claims to higher constitutional authority, the other upon the common people's pragmatic extra-legal actions - are portrayed as if, borrowing Disraeli's well-known metaphor, they were two trains traveling by parallel tracks which head in the same direction while never meeting. Such an understanding of these two legal languages, of course, is troubling. On one hand, the American Revolution is described as a sophisticated and somewhat rarified ideological transformation authored by bourgeois radicals, and awaiting its apotheosis nearly two decades later in the Constitutional Convention at Philadelphia. It is, on the other hand, a popular insurrection centered in the streets, looking backwards to the tradition of Anglo-American popular radicalism, but divorced from the soon to emerge law-centered world of the Early Republic.

This essay rejects the very notion that either paradigm, constitutionalism or antinomianism, reflect the full engagement of revolutionary Americans with legal consciousness. Instead, it seeks to show through a pair of micro-historical close readings precisely how significant was the interaction between official justice and extra-official legal public opinion. Common people spoke the language of common law. Citizens of revolutionary Boston inserted themselves into the process of legal interpretation, evaluating evidence, interpreting doctrine, and determining procedural issues. Instead of an antinomian rejection of legal norms, Bostonians in the revolutionary period recast those norms. But neither was this popular legalism simply derivative from constitutional claims to higher law. It emerged out of interpretations of the technical règlement of common law rules and conflict over the deciding of specific cases.

To fully understand the complexity of revolutionary readings of law requires close readings of contemporaries interpreting cases. In the two Boston cases we will examine, those of Ebenezer Richardson and Levi Ames, opinions delivered in broadsides, newspapers, and the street overturned official sentences. Ebenezer Richardson, a customs officer who accidentally shot a rioter in 1770, was freed by the authorities. Nevertheless, many Boston citizens thought him guilty of murder. But when a career criminal, Levi Ames was sentenced to be hanged for burglary in 1773 there was a popular outcry against the harshness of his punishment. Both began with outrage about a single incident which later swelled into a broad critique of English justice. In fact, Bostonians intertwined the two controversies by contrasting Richardson's pardon for the more serious crime of murder with the execution of Ames for a property crime.

At the center of popular understandings of law was the notion of placing blame. Revolutionary Americans appropriated both official legal process and popular 
genres, such as execution narratives, used to blame criminals, and attached that culpability to legal regimes themselves. Establishing their roles as interpreters of legal process, late eighteenth-century Americans learned to turn upside down legal hierarchies: judges were judged, codes were shorn of their power. And, most importantly, through the grappling with cases, evolved a language of law that was both norm-centered and radical at the same time.

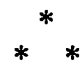

«If there was even a color of justice in the public opinion », wrote John Adams about Ebenezer Richardson, «he was the most abandoned wretch in America. Adultery, incest, perjury were reputed to be his ordinary crimes. His life would exhibit an atrocious volume». Adams comment is revealing. Colonial felons awaiting hanging would come with just such a volume: an execution narrative. A biographical study of transgression, the execution narrative would catalogue earlier arrests for theft, counterfeiting, or the like. By commenting that Richardson deserved his own execution narrative, Adams suggests the need to see him as a common felon. Yet Richardson lacked the trail of felonies that marked the life most executed criminals. Public opinion had the task, then, of constructing a fictive biographical narrative that would justify treating him like any other murderer. Lacking a narrative tale for his crime, it was necessary to invent one ${ }^{2}$.

Little is known about Richardson's real life. Born at Woburn in 1718, he was a direct descendent of the Richardson brothers who helped found the town in the 1640s. Unlike most colonial felons, he came from a substantial family. Richardson's father owned eighty acres of Woburn land and another fifty-one acres at Stoneham. He left two-thirds of this land to his son Ebenezer. In 1740, two years prior to inheriting his father's estate, Richardson married a widow twelve years his senior. As the daughter of the town clerk, she was equally connected. Perhaps the only documentary hint of Richardson's contentiousness was the suit, only a year after his marriage, against the estate of his wife's deceased husband for support of her three minor children $^{3}$.

Yet Richardson would be transformed into what one newspaper called an «old offender.» In 1770, at the height of the Richardson affair, a remarkable document appeared: a broadside pretending to be a first-person verse confession. Its purpose was to fabricate Richardson's criminal past. The fictive confession called upon his native town of Woburn for testimony: «Woburn, my native place can tell/My crimes are blacker far than Hell/What great disturbance there I made/Against the people and their head.» These verses alluded to a controversy over an adulterous affair that tore apart Woburn in 1752, and laid bare long-standing social divisions within the town. As with many New England towns, the conflict in Woburn centered around

2 Letter John Adams to Dr. J. Morse, 20 Jan. 1816 in Adams, (1851, 10, p.204-210). On fictive biography see: Eakin (1985, p. 181-278) and Laden, (1987, p. 3-29). A small number of essays have explored the narrative literature surrounding condemned felons, including execution sermons, pardon petitions, dying speeches, and execution narratives, in England, France, and America: Sharpe (1985), Linebaugh (1977), Davis (1987, p. 1-35). See also: Cohen (1988).

3 Johnson (1890, p. 213); Vinton (1876, p. 208, 242-244, and 523-524). Middlesex County Probate Records, 24 January 1742/3, 19182. 
the meeting house. In 1728, a young minister newly graduated from Harvard, Edward Jackson, was hired to assist John Fox. Resentment over salaries and duties quickly emerged between the two ministers. Backed by different factions, the battle between the ministers came to a peak after the building of the new meeting house. Fox's partisans threatened secession from the parish. In the midst of this struggle, a widow, Keziah Henshaw, gave birth to an illegitimate child. Perhaps bribed by Fox's supporters, she accused Jackson of being the father ${ }^{4}$.

Accepting Henshaw's accusation, Reverend Josiah Cotton launched a partisan attack on Jackson, claiming he was unfit for the ministry. Jackson sued for libel. The case dragged through the courts with the Court of Common pleas deciding in Jackson's favor. Cotton appealed to the Superior Court, where the jury overturned the lower court's ruling. Legal fees mounted and the acrimony between the factions grew intense. Finally, there was a dramatic discovery which ended the case. A letter to Henshaw, which showed the charges were false and fabricated by Fox's supporters, fell into Jackson's hands. Jackson petitioned the superior court. Reversing a ruling one last time, the court found for Jackson.

What was Richardson's involvement in this affair? Edmund Trowbridge, attorney general of Massachusetts and later justice at Richardson's trial, wrote that Richardson was « very serviceable to me in detecting a conspiracy to father a bastard child on the parson of a parish». It appears, then, that Richardson was somehow party to the events in Woburn and his defense of the falsely accused Jackson ironically may have marked the beginning of work as an informer. There is no evidence of Richardson's paternity. Nevertheless, a number of oddly coincidental facts might incorrectly suggest otherwise. Not only was Richardson from Woburn, but Keziah Henshaw was his wife's younger sister. It appears that another Ebenezer Richardson, not the one who confronted rioters in Boston, married Keziah Henshaw in 1754. And there was one more strange coincidence: Richardson had a sister and a daughter, who lived with him in Boston, both named Keziah ${ }^{5}$.

When Bostonians turned to reinventing Richardson's biography, they enlisted this tale of adultery to serve their purposes. Richardson was to blame for fathering Henshaw's child. Perhaps because of his family connection, he was also charged, as Adam's comment suggests, with incest. In the words of his fictive verse confession: "A wretch of wretches prov'd with child/By me I know, at which I smil'd.» But Richardson was not just accused of adultery and incest, but guilty of homicide as well. Shortly after winning the suit, Jackson died. His death was ascribed to the suffering experienced while defending his reputation. Richardson, according to the confession, killed Jackson: "And thus the worthy man of God/Unjustly felt the scourging rod/Which broke his heart, it prov'd his end/And for the whole blood I guilty stand ». Establishing Richardson as guilty of a prior homicide had important

4 Boston Gazette, 26 February 1770. The Humble Confession of Richardson, The Informer [broadside, 1770]. A Council Conven'd at Woburn, upon the Request of the Rev. Mr. Jackson and the First Church in Said Town To Hear and Advise upon the Great and Advise Upon the Great Difficulties Among Them (1746); Sewall (1868, p. 202-319). Suffolk County Court Records (Boston), 68,714. On the ministry and parish organization as locus of local conflict, see Heyrman (1984, p.182-208 and 273-303). Nobles (1983), and Ulrich (1990, p. 103-133).

5 Public Record Office, hereafter PRO (London), T1/408, 18 March 1761. Vinton, 1876, p. 208-209. Fowle (1990, p. 35-37). Robert Treat Paine's minutes of the trial quotes testimony from Richardson's daughter, Kezia (Adams, 1965, 2, p. 420). 
legal implications. It would legitimize a capital sentence for Richardson. Manslaughter could be pardoned with benefit of clergy for the first offense, but was a capital crime for the second. «The halter now is justly due/For I've killed no less than two.» ${ }^{6}$

Slander of this kind was, of course, not unknown in eighteenth-century American politics. John Malcom, a Boston informer tarred and feathered in November 1774, was called, like Richardson, an «old impudent and mischievous offender». He was accused of mistreating children and having «joined in the murders » of North Carolina Regulators. Nevertheless, Richardson's case was significant because of the way popular politics interjected itself into the judicial process. Richardson was being tried twice: once before magistrates and the other time outof-doors, on street corners and in taverns, where Bostonians debated his guilt. Rumor, fictive tales of fathering an illegitimate child, wild charges of murder, and sustained character assassination, all of which might have been dismissed as inadmissable evidence by an official court, was the very marrow of this rough justice. Such accusations, then, tell us less about Richardson than the popular mood in revolutionary Boston. Adultery was a striking motif to invoke since Richardson, after all, was engaged in political infidelity. His loyalty to neighbors had been transferred to the English ${ }^{7}$. Placing blame through criminal biography fit nicely with the inconsistencies of eighteenth-century criminal justice. Highly selective, this legal system tempered capital statutes with frequent pardons. One felon might be executed and another freed for the same crime. What justified punishment, then, was not simply the felony itself, but the character of the felon. Richardson's fictive biographical narrative addressed this issue. His act of murder might be punished with death because through his entire life he had been a «d-d villain ${ }^{8}$. In Richardson's case, he was an old offender - said to be guilty of adultery, incest, and homicide in Woburn, moreover, he violated community norms emerging from the political conflict between England and America. Responding to English passage of the Townsend Acts of 1767 levying duties on a variety of imported goods, Americans established non-importation agreements. Leading the way, Bostonians identified a long list of English goods that should not be imported, and enforced these agreements through sanctions, boycotts, public scorn, and extra-legal crowd actions against violators.

While contraband tea may be sold according to public opinion, Hutchinson complained, it is «a high crime to sell any from England». Hutchinson's statement was an admission of the ways that law had been turned upside down. While disobeying an act passed by parliament, the non-importation agreement - though lacking any official status - was seen by many colonials as law. A merchant importing contrary to the agreement, Theophilus Lillie, echoed Hutchinson. Through the coercion of the non-importation movement, he claimed that patriots chose «to make laws, and

6 Sewall (1868, p. 319-325); Richardson, Humble Confession. Wood (1982, p. 401-444).

7 Boston Evening Post, 23 April 1770. Another case tried before the Massachusetts Superior Court in 1763, Rex v. Doaks, demonstrates the limits placed upon admission of testimony of past character as evidence. Indicted for having a house of prostitution, the court refused to allow allegations of earlier sexual misdeeds. Quincy (1865, p. 90-91). On language as provocation, see: Rosenberg (1986, p. 12 56) and Bauman (1983). Seduction and infidelity were common late eighteenth-century literary themes. Lewis (1988) examines the political meaning of seduction.

8 Boston Gazette, 5 March 1770. 
in the most effectual manner execute them upon me and others, to which laws, I am sure I never gave my consent either in person or by my representative». But, like England's attempt to halt smuggling, enforcement was difficult. By the fall of 1769 , the merchants' non-importation agreement had broadened as patriots attempted to have all Boston's citizens pledge not to consume those English products improperly imported ${ }^{9}$.

Yet some merchants continued to violate the agreement. Drawing upon the eighteenth-century notion of shame as an integral part of punishment, they were punished through having their crimes publicized. Interestingly, the sanctions themselves took the form of official punishment. Boycott, like official fines, was a monetary penalty. By ostracizing merchants, patriots enforced, as the authorities did with transportation, a form of social and economic exile. Handbills circulated to publicize the names of importers and townspeople were urged to extend their boycott from simply the imported goods to the violators as well. Bostonians, in January 1770 , voted to deny «not only all commercial dealings, but every act of common civility » from merchants who were especially fragrant violators. Four merchants John Taylor, William Jackson, Nathaniel Rogers, and Theophilus Lillie - were singled out for special abuse. Schoolboys taunted them, their houses and shops pelted with dirt, and potential customers intimidated. Defaced shop signs were replaced with placards warning against buying from them. Three February Thursdays in a row, market day in Boston and a school holiday, crowds gathered at the merchants' homes ${ }^{10}$.

On the last of those Thursdays, February 22nd, a crowd collected at Lillie's home. A placard painted with the features of importers was erected pointing towards the house. According to one account of the event, Richardson, who lived nearby, became enraged by the sign. He urged others to knock it down with their wagons. No one responded so he seized a cart and attempted to knock it down himself. Richardson and the crowd traded insults. Retreating to his home, he vowed to defend it with a seaman, George Wilmot, who appears to have had connections with the customs commission. But despite the danger, there was a theatrical, almost farcical touch to the riot. Richardson and his wife repeatedly went into the street and menaced the schoolboys who had gathered. When the boys began throwing light rubbish, Richardson responded by pointing a gun out his door. Angered by this threat of violence, the crowd pelted the house with stones. Windows were broken. According to a sympathetic source, Richardson used his weapon only after being struck quite hard with a rock. He fired a volley of bullets, wounding two schoolboys. Eleven year-old Christopher Snider, struck in the chest and pierced by almost a dozen bullets, would die later that night ${ }^{11}$.

9 Boston Post-Boy, 30 November 1767. Schlesinger (1957, p.91-155 and 179). Dickerson (1951, p. 190-202). Hutchinson, letter to Hillsborough, 27 April 1770, 25 Massachusetts Archives (Boston). Massachusetts Gazette, 11 Jan. 1770.

10 Boston Gazette, 26 February 1770; "At a Meeting of the Merchants of Traders at Faneuil Hall on the 23rd of January, 1770" [broadside]; Hutchinson (1936, 3, p. 193). Maier (1972, p. 114-130), Schlesinger (1957, p.156-183), Nash (1979, p. 352-360).

11 Sparks Manuscripts, Houghton Library (Harvard University), New England Papers, 16 March 1770, 3:69; Boston Evening Post, 26 February 1770; Boston Gazette, 26 February 1770, Connecticut Journal and New-Haven Post Boy, 9 and 16 March, 1770; Hutchinson letter, 23 February 1770, 26 Massachusetts Archives, 446-447; Boyle (1930, p. 262); Hoerder (1977, p. 219-223); Adams (1965, 2, p. 396-400). 
When Richardson first encountered the non-importation placard, he repeatedly cried out «perjury, perjury ». This was somewhat ironic because Richardson himself would suffer from that same accusation. Most likely alluding to Richardson's role in providing testimony against smugglers, Adams listed perjury among his crimes. In many ways, Richardson and the Boston crowd shared the same task: they sought to identify those who broke either official or unofficial codes. Whether with depositions, as Richardson made against smugglers, or with placards, handbills, and taunting leveled against importers, language was the instrument used to wage the political and legal battle. No other term was so frequently used about Richardson as informer. "An informer», went one description, «and consequently a person of a most abandoned character». Richardson's fictive verse explains: "But yet still wicked, yet still vile, I've liv'd on honest merchants' spoil/For this I justly got the name/The informer, though with little gain ${ }^{12}$. After the shooting, the mob seized Richardson and Wilmot. More people gathered as the bell at the New Brick meeting house was rung. The riot and shooting demonstrated that civil authority had broken down in Boston. What should be done with Richardson? The first thought was to hang him up at once, Hutchinson claimed, and a halter was brought. But patriot leader William Molineux rescued Richardson from hanging, and brought the prisoner before Justice of the Peace John Ruddock ${ }^{13}$.

The justice of the peace consigned Richardson to constables who escorted him to Faneuil Hall. They had to contend with «the mob endeavoring to put a rope around his neck and take him from the constables to execute him themselves ». At Faneuil Hall, Richardson was examined by a panel of judges - Richard Dana, Samuel Pemberton, and Edmund Quincy - and sent to prison for his own safety. Here, too, the public interjected itself in judicial proceedings. Over a thousand people, according to one newspaper's count, were present at the examination. Popular justice and official justice were not distinct and separate spheres, as historians have often suggested, but intertwined. Peter Oliver, Tory chronicler of the early stages of the American Revolution, claimed that reliance upon the courts was simply a question of convenience: "As the term of the Supreme Court was very near, and they thought that the blood of the unhappy youth, which had been spilt would not be cold before the court met; and they were pretty sure that they could procure a jury for conviction, so some of the leaders of the faction chose that he should be hanged by the forms of law, rather than suffer the disgrace of hangmen themselves ${ }^{14}$.

12 Boston Evening-Post, 26 February 1770; Virginia Gazette, 5 April 1770; «Robert Treat Paine's Minutes of the Trial ", in Adam's 1965, 2:417-418. On Richardson as informer, see: Boston Gazette, 26 February 1770 and 5 March 1770. Samuel Adams called Richardson an informer, «such a one as was never encouraged under any administration but as those of Nero and Caligula ». Writings of Samuel Adams, 1 :89-96). Richardson, Humble Confession; Richard Reeve, writing for the customs commission, denied that Richardson was ever employed by them (Boston Gazette, 5 March 1770). Nevertheless, it appears that this was simply an attempt by the authorities to distance themselves. Hutchinson, Massachusetts Bay, 3:193.

13 Hutchinson to Gage, 25 February 1770, Hutchinson to Hood, 23 February 1770, 26 Massachusetts Archives, 444, 445, 448. Paine's Minutes, Adams (1965, p.417); Oliver (1961, p. 84-85).

14 Sparks Manuscripts, New England Papers, 3:69. Boston Evening-Post, 20 February 1770; Virginia Gazette, 5 April 1770; Massachusetts Weekly Gazette and Boston Weekly Newsletter, 1 March 1770. Oliver, Origin and Progress, p. 85. 
Nevertheless, as will be argued, the patriots and rioters chose to work with the system of official justice because they shared a common legal discourse. Through this discourse many Bostonians who might have rejected the idea of lynching Richardson in the emotional aftermath of the shooting would come to demand his execution. Not long after his arrest, a placard was hung on the Liberty Tree, stating that «thou shall take not satisfaction for the life of a murderer - he shall surely be put to death». The placard, of course, borrowed an apodictic biblical form in order to appeal to legal codes. It must be seen as a statute: publicized, like official statutes, and including both an authoritative injunction and a sanction ${ }^{15}$.

But the construction of vernacular legal narratives extended beyond the invention of criminal biography and the making of codes. It seized upon well-publicized English Wilkite cases to find legal precedents. Snider was repeatedly compared to Britain's Wilkite martyr William Allen: "The blood of young Allen may be cover'd in England », wrote a colonial radical, «but a thorough investigation will be made in America for that of young Snider». Such Wilkite imagery seemed especially resonant to colonial Americans. Like Snider, Allen was a bystander. He was shot only a year earlier during the St. George's Fields Massacre of 1769 when supporters of Wilkes were routed while they gathered to cheer their imprisoned leader. As the Richardson case remained unresolved, it must have appeared increasingly similar to London's failure to punish the soldier who shot Allen. But it was clearly not the unsatisfactory verdict in the Allen case that appealed to Bostonians. Instead, the English case served as a precedent for a politicized reading of criminal legal process. Not surprisingly, then, Richardson, too, was recast as yet another typological figure in the Anglo-American radical canon: John Porteous.

"The conduct of freemen in one age is frequently imitated in another», warned a Massachusetts newspaper. "Another Porteous may fall in this country, and by an awful example... he that sheddeth man's blood by man shall his blood be shed ». This appeal to Porteous' example was telling. The Porteous affair began in 1736 with the hanging of a smuggler in Edinburgh. Showing their displeasure at the execution, spectators pelted the city guard with stones and dirt. John Porteous, captain of the guard, responded by opening fire. Six or seven people were killed and over twenty wounded. Although a jury found Porteous guilty of murder and he was sentenced to death, his life was spared through a royal reprieve. Angered, a mob stormed the prison, seized Porteous, and hung him on the city gallows. What happened in Edinburgh during the 1730s was relevant for revolutionary Boston. The affair was set in the context of a struggle between Scottish autonomy and the power of the crown. Richardson, like Porteous, killed a rioter and somehow eluded justice. Interestingly, Boston radicals were mustering a variety of Anglo-American precedents for vigilante action in the same way that law courts would draw upon earlier cases. If Porteous could be executed by extra-legal means for murder, why not Richardson ${ }^{16}$ ?

15 Sparks Manuscripts, New England Papers, 3: 69; Virginia Gazette, 5 April 1770; Connecticut Journal and New Haven Post-Boy, 9-16 March 1770; Boston Gazette, 5 March 1770.

16 Massachusetts Spy, 5 March 1772. In Mercy Otis Warren's play The Adulateur: A Tragedy (Boston, 1773), an attack on Hutchinson with classical motifs, a character named Portius - almost certainly a pun on Porteous - calls for revenge against Richardson. Gentleman's Magazine, 1736, p. 230 and 1737, p. 121 and 346-7; Act of Council against Throwing Stones \&c. at the Execution of Criminals (Edinburgh, 1737); Howell (1816-1828, 17, p. 923-994); Dickinson, Logue (1976, p. 21-40). 
On April 20th the Richardson trial began. Since no lawyer agreed to defend him, the court appointed Josiah Quincy as counsel. Samuel Quincy and Robert Treat Paine shared the role of prosecutor. Paine's roughly sketched minutes of the trial, read together with the public debate over the proceedings, provide a unique opportunity to explore the differences between popular and official definitions of criminal law. How did the categories of official and unofficial justice differ? In what ways were Bostonians willing to construct their own codes? And how, ultimately, did the common people respond to the very different decision of the court? The major issue at stake was the definition of the crime - more precisely, the distinction between manslaughter and murder ${ }^{17}$.

Such a distinction was one of the peculiarities of official English law. French law, for example, treated homicide as a single crime until the Napoleonic Code. «I don't know of a nation in the world », a Massachusetts grand jury was told in 1767, «that makes that distinction between murder and manslaughter which the English do». Following Biblical precedent, the earliest Massachusetts settlers failed to include manslaughter in its legal codes. Even in England, it was only in the late sixteenth-century that lawyers distinguished between murder, a capital crime for the first offense, and the less severely punished felony of manslaughter ${ }^{18}$. Manslaughter turns upon the issue of intent. Juries were entrusted with making subtle judgments about the emotional state of the felon at the brief, often confused moment when the crime occurred. Underscoring this unusual need to weigh intent, Blackstone defines manslaughter as «the unlawful killing of another, without malice either express or implied, which may be either voluntary, upon sudden heat or involuntary...it must be done without premeditation ${ }^{19}$. In Richardson's case, then, two questions needed to be asked. First, what was his intent at the time of the shooting? And, secondly, to what extent Richardson might be permitted to raise the justification of self-defense?

Richardson's defense first sought to show that he lacked any premeditated intent to kill Snider. In notes compiled while preparing for the trial, Josiah Quincy outlined the strategy for the defense: "To explain the nature of the crime of murder and the different kinds of homicide, as justifiable, excusable (as se defendo) and felonious: to show the distinction between felonious homicide of malice prepense, which is properly murder, and without such malice, which is manslaughter». Richardson, Quincy argued, acted without malice of forethought. The shooting took place in the heat of anger. The very fact that Snider was a bystander, struck by a stray bullet, shows that Richardson did not intend to kill him. Certainly, with patriot instigators present, Richardson must not have been aiming at an unknown schoolboy. «If A shoots at B, misses him and kills C», the defense admitted «it would have been murder». Yet if it was true both that Richardson fired out of sudden passion and the

17 Robert Treat Paine, «Paine's Minutes of the Trial » and «Paine's Minutes of the Proceeding on the Motion for a New Trial» in Adams (1965, 2, p. 416-430). The manuscript is in the Massachusetts Historical Society, Robert Treat Paine Papers.

18 Charge to the Grand Jury, March Term, 1767, in Quincy (1865, p. 232-237). The distinction between murder and manslaughter appears later in Massachusetts law, see the 1647 statute defining justifiable homicide in The Charters and General Laws of the Colony and Province of Massachusetts-Bay (Boston; T.B. Wait, 1814, p. 150). 
victim was not the intended one, then, according to precedent, the charge should be reduced to manslaughter ${ }^{20}$.

Official Anglo-American law understood malice of forethought as a specific and premeditated intention to harm another. Yet at the level of popular judicial discourse, there was no doubt that malice - more broadly defined - was behind Richardson's crime. As his fictive biography suggests, Richardson was thought malicious by nature and habit. «Urged on by hell and malice unprovoked », claimed a 1773 drama about Richardson, "hurled through the crowd promiscuous death and slaughter». Witnesses at the trial echoed this perception. They portrayed an ill-tempered, vindictive man whose violent language betrayed his willingness to commit murder. Months before being faced with an anti-importation crowd, according to one witness, Richardson said «Let 'em come on me I'm ready, for I've guns loaded ». During the course of the riot, he threatened to massacre the mob, adding «I'll make it too hot for you before night». Richardson showed no remorse about Snider's death. «Damn their blood», he was reported to have declared after the shooting, «I don't care what I've done ». Richardson may not have intended to slay Snider, but, it was thought, he clearly wanted to kill someone in the crowd. How was it possible, Bostonians must have wondered, not to see malice behind Richardson's act?

Richardson was not an easy felon to defend. «Every newspaper was crowded with the most infamous and false libels against him in order to prejudice the minds of his jury ». Faced with doubts about Richardson's character, his counsel crafted an argument based upon self-defense. Richardson «was in his house peaceably and there assaulted, by breaking his windows and throwing stones at him». «It is excusable homicide se defendendo », Quincy recorded in his trial notes »,... a man's house is his castle and he may defend it». The plea of self-defense had the advantage of subtly shifting the argument from Richardson's emotional state at the time of the act to solid facts, from the troubling persona of Richardson himself to his home. Yet the spatial configuration of the riot was also open to debate. What defined the boundaries between house and public sphere? Even in the midst of the riot, there was an engagement with the legal meaning of these boundaries. At one point, when Richardson ordered the rioters to disperse, they retorted «king's highway ». The protesters were making a legal argument. Outside Richardson's house was, like any thoroughfare, public space where a demonstration may take place. Richardson did not agree. He threatened to make his own highway by firing his gun through the dense crowd ${ }^{21}$.

The dramaturgy of the confrontation took place at the liminal space between the private and public. As with most anti-importation protests where houses were pelted with dirt, rioters resisted the temptation to forcibly enter them. In this case, Richardson dashed out of his home to confront the crowd, but retreated when he felt

20 Adams (1965, p. 411-416). The manuscripts of two judges at Richardson's trial, show a firm grasp of the distinctions between murder and justifiable homicide. Trowbridge's papers contain notes entitled «Cases adjudged a Homicide», in Edmund Trowbridge, «Notes on Legal Actions and Extracts from Cases E-H », Dana Papers, Massachusetts Historical Society (Boston). In 1780, Cushing elaborated upon a manslaughter decision in a case where throwing stones led to the violent death of a child. William Cushing, Indictment v. Daniels, «Notes of Cases Decided in the Superior and Supreme Judicial Courts of Massachusetts 1772-1789», Manuscripts, Harvard Law Library (Cambridge).

21 Sparks Manuscripts, New England Papers, 3: 76, 23 April 1770. Adams (1965, 2, p. 411-425). Warren, Adulateur, p. 10-11. 
threatened. This back and forth movement reflected the distinction between Richardson's home and the street. He «challenged them up to [the] door». The door as boundary repeatedly appeared in testimony at the trial. Richardson was reported to have said a day before the riot that violence would erupt if effigies were posted «before importers doors». Acknowledging the demarcation it signified, «boys got to the door, threw things». Nevertheless, this threshold remained a line that would not be crossed. Patriot agitators at the riot, according to the deposition of Richardson's daughter, «followed father up to the door and said come out you damn son of [a] bitch». Although the "front door [was] open, nobody had attempted to enter». Only Richardson's family would testify that the door had been broken open. But even they did not claim rioters had barged into their home ${ }^{22}$.

Such legal definitions of space were at the crux of Richardson's claim to selfdefense. Quincy's notes for defending Richardson show a fascination with the threshold as boundary, asking «how far the attack upon the house was carried; whether and to what degree the windows were demolished before the firing, and whether the door was broken open, and any attempt made upon it; whether any actual attempt made to enter; or any evidence of such design from threatening words». Windows, like doors, were considered openings subject to being violated. For rioters, hurling stones through windows may not have breached borders between Richardson's home and the street. Those throwing, after all, remained outside. But the evidence of defense witnesses suggests that broken windows could also be seen as a kind of forced entry. One of Richardson's daughters described the destruction of the window until there was «no lead, no frame ${ }^{23}$.

Seeking to mitigate Richardson's crime, Hutchinson also attributed a special significance to windows. «At length pelted and drove into his house...», Hutchinson wrote, « and as he says windows broken and his person in danger, he fixed upon the multitude and killed one lad and wounded another $\aleph^{24}$. What was the legal model for this association of openings with violation? Rape and housebreaking share the same concern with defining the penetration of private space. Yet both demand actual entry for full prosecution. Bostonians who denied Richardson's claim to self-defense appear to have been concerned with such legal distinctions. A juror who found Richardson guilty of murder said he would have acquitted him «had the killing happened in the night instead of the day ». This comment demonstrates a remarkable appropriation of Anglo-American law. It mimics the traditional English statute on housebreaking which permitted the killing of a burglar in self-defense at night, but not during the daytime. The call for finding Richardson guilty of murder, as well as the claim that his crime was simply manslaughter, was rooted in a legal discourse $^{25}$.

«The prisoner», Richardson's judges told jurors, «was attacked in his own house by a number of tumultuous people in that what he had done was his own

22 Adams (1965, 2, p. 416-420).

23 Adams (1965, 2, p. 411-421).

24 Adams (1965, 2, p. 411-421); Hutchinson letter, 23 February 1770, 26 Massachusetts Archives, 446447.

25 Oliver (1961, p.86). 23 Hen. VIII, c.1 (1531) and 1 Edw. VI, c.12 (1547). The distinction between housebreaking at night and during the daytime was eroded by later statutes. See: Radzinowicz (1948, 1, p. 141-149). 
defense ». These instructions to the jury made clear the bench's interpretation of the law: it was justifiable homicide - manslaughter, not murder ${ }^{26}$. The Superior Court justices would later be accused of acting under the influence of politics. Yet their call for the jury to choose a verdict of manslaughter would have been standard for any similar case. In 1767, three years before Richardson was indicted, the Massachusetts Chief Justice's address to a grand jury dealt with the very issue of justifiable homicide in the course of a riot: if a man is attacked in his «own house, whether it be to treat him contemptuously for the diversion and sport of those who assault him », he will be guilty only of manslaughter with benefit of clergy. But the bench may have overstepped its procedural role by urging the jury to find for manslaughter. While today suspects are charged prior to the trial with the appropriate category of homicide, during the eighteenth century the indictment of any homicide suspect, no matter how mitigating the circumstances, was always murder. It was the role of the jury to temper the murder charge and declare the crime to be simply manslaughter ${ }^{27}$.

The jury in the Richardson case refused to cooperate. After a lengthy deliberation from eleven in the evening until early the next morning, the jury returned its verdict on April 21st: Richardson was guilty of murder. Wilmot was found not guilty. When the verdict was read, spectators clapped and cheered. Peter Oliver noted the inversion of traditional courtroom etiquette. «At acquittals there is often a huzza of joy in the hall of justice; but it is singular at a conviction. But now, the courtroom resounded with expressions of pleasure». The justices were faced with a dilemma. How should they respond to such a blatant disregard of the court's instructions? Did the jurors, as Hutchinson asked, think «themselves better judges of the law than the court?». How could they «be obliged to give judgment upon a verdict which appeared to them directly against law ?». It « was difficult, in the state of the town, to order the jury out a second time, or to refuse or delay sentence after the verdict was received ${ }^{28}$. In effect, two conflicting judgments had taken place: the manslaughter decision of the judges based upon traditional categories of official law and a judgment out-of-doors - encapsulated by the jury's verdict - that defined Richardson's crime as murder.

Such competing legal authority evoked a major late eighteenth-century legal debate. Were juries simply empowered to determine the facts of a case or could they decide law? The medieval criminal trial jury functioned as a witness. It determined the circumstances of a crime and the credibility of testimony. By the mid-seventeenth century, however, the increasing discretionary powers of juries was met by the judiciary's attempt to curb them. Bushell's Case in 1670 established the principle that judges cannot coerce a jury to declare a predetermined verdict. Yet for the next century the rights of juries remained ambiguous. While, on one hand, law was considered too complex for lay people to decide, it was also thought that overturning their verdicts threatened to undermine the independence of the jury. In most cases, juries followed advice from the court. During the 1760 s, however, this debate became increasingly relevant. A number of English seditious libel trials with strong political overtones made the question of jury autonomy a watchword for Wilkites and other

26 Sparks Manuscripts, New \&ngland Papers, 3:76. Oliver, (1961, p. 86).

27 Quincy $(1865$, p. 263). Beattie (1986, p. 77-81).

28 Oliver (1961, p.86); Hutchinson letter, 21 April 1770, 26 Massachusetts Archives, 463; Hutchinson, Massachusetts Bay, 3, 206. 
radicals. In both Rex $v$. Williams (1764), which defended the publishing of Wilkes' North Briton, and a 1770 trial of the printers of the Junius letters, Wilkite lawyers based their defense upon right of juries to determine the law against instructions from the bench. Both cases were widely reported in the colonial press. Another case, Smith v. Taylor (1770), concerning a political brawl resulted in death, shared certain similarities with the Richardson trial. Despite the judge's determination that it was manslaughter, Wilkites sought a murder charge ${ }^{29}$.

John Adams linked the attempts to undermine the power of juries in both England and America. At the very time that Richardson's fate was debated and Wilkites were creating a furor in London courtrooms, another Massachusetts trial brought to the fore the question of whether juries had the right to decide law. John Mein, the contentious anti-patriot publisher of the Boston Chronicle, owed a sizable debt to Thomas Longman, a London merchant. For overtly political reasons, John Hancock initiated a lawsuit to recover the claim. The suit was a patriot ploy to harass Mein. Although the bench directed the jury to find for Mein, it chose to do just the opposite. Longman v. Mein (1770-1771) prompted the claim that eighteenth-century Massachusetts juries could determine questions of law. Writing in his diary at the time of the trial, Adams politicized the legal issue of the jury's role: "No wonder... that attempts are made to deprive the freeholders of America...of this troublesome power so dangerous to tyrants ». For Adams and other American radicals, the jury was invested with democratic authority. It was, in his words, «the voice of the people $»^{30}$.

Conflicts between judges and juries were not common. Adams estimated that in only one out of a thousand cases would the jury be at a loss about the law. But the question of a jury's right to determine law as well as fact revealed how eighteenthcentury Americans had began constructing a popular ideology of justice. It privileged the experiential or intuitive wisdom of juries over the learned legal knowledge of judges. The juror was to be flexible, drawing upon their understanding of witnesses character and local knowledge to reach a decision « according to his own best understanding, judgement, and conscience». Underscoring the place of conscience in the jury's decision, Adams claimed that juries should not be coerced to submit a verdict against their will. The jury should not be made « a mere machine». This sort of legal epistemology meant a radical recasting of roles. Some colonial writers even doubted the right of judges to interpret the law: «The opinion of a judge is respectable if he be an honest man, but neither the opinion of a judge or any court of justice

29 Brewer (1980, p. 153-159) describes the jury's political role in English seditious libel cases. Beattie, (1986, p. 406-410); Mitnick (1988, p. 201-235). John Langbein and Thomas Green have provided the most thorough discussion of the changing role of the jury. See: Langbein (1983); Green (1985, p. 267-317). The debate over the right of juries to determine law as well as fact inspired a number of polemic works in the 1760 s and 1770 s, most notably Joseph Towers (1764), Robert Morris (1770), George Rous (1771). For the colonial response to this debate, see, for example: Boston Gazette, 13 March 1769 and 4 February 1771.

30 Adams (1965, 1, p. 199-230). Adams (1962, 2, p. 3-5), Stimson (1990, p. 71-79). Based on considerable research, Nelson (1975) argues that Massachusetts juries had the power to judge both law and fact, and that the exercise of that power remained virtually unchallenged. Nevertheless, as a question of legal authority the power of juries was subject to debate. Those politicized cases where consensus between judge and jury did not exist demonstrated how little agreement there was on this issue. Recent work underscores the ambiguity of the distinction between judging law and fact in the colonies prior to the mid-eighteenth century: Mann (1987, p. 74-81). See also, Krauss (1988). 
was intended to determine any issue.» "They may advise» the jury, suggested an anonymous 1772 essay, «but it is the finding of the jury which is the determination and interpretation of the law $»^{31}$.

What Adams comments suggest, then, was how differently juries might be perceived - and how that perception might be altered by politics. At stake was not simply the legal role of juries, but its place in late eighteenth-century political mythology. There were two conflicting understandings of the identification of juries with the common people. Adams thought of the jury as analogous to the legislature. It restrained the bench just as parliament was meant to balance the power of the crown. Peter Oliver, conversely, viewed the jury at Richardson's trial as simply an extension of the mob. "A demonocracy», Oliver called it. He accused Boston selectmen of stacking juries so that only those with patriot political sympathies would participate. Richardson, according to Oliver, «fell into the hands of tigers, [jurors] whose tender mercies were cruelties». The jury foreman spoke with a "sullen pride of revenge». Such an accusation of vengeance struck at the heart of the mitigating function of the eighteenth-century criminal trial jury. Juries were meant to temper the punishments of a code laden with capital statutes by undervaluing stolen goods, what Blackstone aptly called "pious perjury », or reducing charges to a clergyable offence. Yet the jury at the Richardson trial did just the opposite. It acted against the defendant. After the trial, one juror said that he had agreed to the murder charge only because «the court had delivered their opinion in law that the prisoner was innocent, and that his life would be saved». A significant inversion had taken place. Ignoring the charge from the bench, the jury demanded the right to punish and, ironically, left to the judges its customary task of mitigation $^{32}$.

In their attempt to lessen Richardson's punishment, the justices followed a classic legal strategy: delay. They remanded him to prison, partly for his own safety. Richardson's defense counsel lodged a petition for a new trial; and the court, hoping to avoid another inflammatory legal battle, quietly consulted London about a pardon. The patriot press was quick to embrace Wilkite notions of the law. It argued that juries could judge not just fact, but law. «The notion of the jury's having no power to intermeddle with law is without foundation in law ", protested an essay in the Massachusetts Spy, «it appears to me a perversion of justice and making a jury mere machines ». «We see already the affect. A wretch, though by his country and a jury regularly sworn declared guilty of premeditated murder, yet lives exulting over the justice of his country ». The debate about Richardson's fate was both within a legal discourse - using courtroom idiom to argue about such questions as due process and the role of juries - and, at the same time, a direct challenge to legal authority. Richardson, Hutchinson declared, was found guilty «against the opinion of the court». Yet the passage quoted above revealed a very different understanding of authority. It offers two alternative sources of judicial power: jury and, significantly, 'country' - or public opinion. The question « who will judge?», was answe-

31 Massachusetts Spy, 9 May 1771 and 20 February 1772. Adams (1962, 12 February 1771, 2, p. 2-5). Nelson (1978, p. 893-960).

32 Adams (1962, 2, p. 3-5), Oliver (1961, p. 85-86). Green (1985, p.305-357). Hay (1988) sheds doubts upon the democratic pretensions of eighteenth-century jury. Property qualifications shaped the jury as a class institution. Of course, choosing a jury was no different in this regard than electing legislatures. 
red by investing not just the jury, but the common people with a previously unimagined legal authority ${ }^{33}$.

In Rex $v$. Wemms, Justice Edmund Trowbridge instructed the jury to rely only upon evidence heard in court, not upon "what you may have read or heard of the case out of court». But during the Richardson trial, the borders between courtroom and street corner dissolved. Eighteenth-century courts were as much social constructions as architectural ones. More than anywhere else in colonial society, except churches, they demarcated a special place ruled by its own rituals and authority. Perhaps this was because what took place in courtrooms was laden with the threat of sanctioned violence. Courts, after all, had the right to expropriate wealth, deny liberty, or even take away a person's life. This awesome power, bounded by rules, was reflected in the architecture of the Superior Court chamber. It was, according to John Adams' evocative description, "as respectable an apartment as the House of Commons or the House of Lords in Great Britain, in proportion, or that in the State House in Philadelphia». The physical setting was dominated by the justices. « Round a great fire, were seated five judges...arrayed in their new, fresh, rich robes of scarlet English broadcloth; in their large cambric bands, and immense judicial wigs». This dignity, "more solemn and pompous than that of the Roman Senate», underscored the well-staged distinctions between court ritual and extralegal crowd action ${ }^{34}$.

Instituted by Hutchinson in 1762 , judicial robes were a novelty for Massachusetts Superior Court. Such trappings of power demonstrated not the hegemony of law courts, but the need to bolster waning power. A few years later, Hutchinson would elaborate upon sustaining the authority of the Superior Court: "Tis on the dignity and support of the executive courts that your own liberty depends. Let the respect of these courts be lost, let their dignity not be kept up... and all order and government will soon be at end. For what order can there be in a society where the courts which are to carry the laws in execution are treated with a contemptuous disrespect?». Faced with rising discord, two years later New York's justices, William Smith, Daniel Horsmanden, and Robert Livingston, would also require gowns to create «dignity, authority, solemnity, and decorum». But robes do not make the judge. In a satirical play published in Boston, Justice Beau has to duck into his chambers to put on a robe before taking a deposition. "Be sure», says the vain justice, « to see my Whig is combed and powdered». The use of robes may not have ensured deference. It did, however, reflect Hutchinson's hierarchical vision of justice: while robed justices rendered decisions in well-appointed courtrooms, unruly common people were best consigned to Boston's tumultuous streets ${ }^{35}$.

33 Massachusetts Spy, 9 May 1771 and 2 May 1771; Hutchinson correspondence, Massachusetts Archives 26, 463, 21 April 1770.

34 Trowbridge's Charge to the Jury, 5 December 1770 in Adams (1965, 3, p. 282-302); John Adams to William Tudor, 29 March 1817 (Adams, 1851,10 p. 244-245). The cultural significance of the courthouse in eighteenth-century America is best described in two works on Virginia: Isaac (1982, p. 8890) and Roeber (1981, p. 73-95). Other studies of the court as distinct space, include: Rosen (1989, p. 1-19), Hay (1975). See also, Wilf (1993, p. 51-78).

35 Hutchinson, Charge to Grand Jury (1767) in Quincy (1865, p.245-246). Adams (1962, p. 54-58). Trial of Atticus Before Justice Beau for a Rape (Boston, 1771), p.6. Murrin (1966, p. 238). On instituting judicial gowns in New York, see: Manuscript of Moot Cases, 1770-1774, New York Historical Society, 26 July 1774. Greenberg (1976, p. 223-224). 
Yet Richardson's case brought the crowd into the courtroom. A vast number of spectators gathered to hear the proceedings. "The authority of the courts », wrote Peter Oliver, «were now of little force. Forms were maintained without much power ». Nowhere can this better be seen than during the instructions to the jury. From Justice Oliver came a statement assigning broader guilt to patriot leaders. He «charged the death of the boy upon the promoters of effigies and other exhibitions which had drawn the people together and caused unlawful tumultuous assemblies ${ }^{36}$. Such a statement from the bench meant that Oliver took advantage of the presence of another patriot crowd to «charge» them (the use of legal language is significant) with the crime. When the bench unanimously called upon the jury to reduce the crime to manslaughter, anger flared. "No manslaughter, but murder», Bostonians shouted at the departing jurors, «remember jury you are upon oath blood requires blood ». The crowd chose to deliver their own instructions to the jury. This charge, like the official one read from the bench, centered around the distinction between manslaughter and murder, and jurors' responsibility in framing a verdict. When the jury decided that Richardson was guilty of murder, the spectators cheered. Richardson himself was whisked away to jail in order to prevent his being lynched. He would spend the next twenty-two months in prison awaiting a pardon. Prompted by what the defense considered intimidation of the jury, a motion for a new trial was quickly filed. This troubled case, clearly, would not set any official legal precedent. Nevertheless, it marked a watershed in the popular wresting away of judicial power. Almost every step of the affair Bostonians would declare judgements, craft fictive criminal narratives, search for precedents, decide questions of law, or charge a jury ${ }^{37}$.

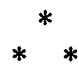

While Ebenezer Richardson languished in prison, Levi Ames pursued his criminal career. Ames did not need anyone to invent past felonies for him. From his earliest childhood, Ames led a life punctuated by crime. Beginning with minor thefts, a couple of eggs, a pocket knife, and some chalk, he quickly graduated to robbery as a profession. Like Richardson, Ames had a verse broadside that justified his execution: «No goods were safe that you could steal/How many doors you've open broke/And windows scal'd and money took/Round houses you have all day been/To spy a place to enter in». "Death and damnation», adds the poem called The Speech of Death to Levi Ames, is your due ${ }^{38}$. Such verse dying speeches, the execution sermons preached by Boston ministers, and his long, rambling execution narrative would leave no doubt that Ames - in ways that might never apply to Richardson was an old offender.

Born at Groton in 1752, Ames was only twenty-one years old when sentenced to death. His father, Jacob Ames, died when he was age two. This loss seems to have

36 Hutchinson to Hillsborough, 21 April 1770, 26 Massachusetts Archives, 463. Unfortunately, a surviving diary from one of the justices sheds little light on the workings of the bench in this case: Benjamin Lynde, Jr. (1880, p. 194-195).

37 Oliver (1961, p. 86) and Adams (1965, 2, p. 404-405 and 426-427). 
determined much of his early life. Finding herself unable to discipline her child, Ames' mother contracted an apprenticeship agreement. Ames ran away from his master. This, he admitted, was the beginning of his ruin. «For being indolent in temper and having no honest ways of supporting myself, I robbed others of their property ». Richardson was emblematic of the kind of scoundrel who would do anything for his master. He was, in late eighteenth-century idiom, a creature of the customs commissioners - willing to lie, inform, or even murder at their bidding. But Ames represented another bête noire of colonial Americans, the masterless man who wandered freely without norms imposed by social superiors ${ }^{39}$.

Not surprisingly, then, Ames' execution narrative was constructed around the motif of motion. It was a sort of felon's progress, a grand larceny tour making its way across much of New England. Thefts were marked by where they took place: Waltham, Cambridge, Lexington, Natick, Boston, Marlborough, Watertown, Newburyport, or Worcester. Ames' crimes traversed three colonies, Connecticut, Rhode Island, and, especially, Massachusetts. After one arrest, he wandered like Cain with a mark. Ames' forehead was branded with a «B $»$ for burglary. Ironically, Ames began his tale of theft at Richardson's home town: Woburn. There he stole a gun from Josiah Richardson, probably a relative of Ebenezer. Quickly moving on, Ames stole twenty to thirty dollars at Plymouth, broke into a dry goods store at Groton where he took some cloth, and robbed two Waltham men of money and a hat.

Yet even such petty thefts as the hat were accompanied by the name of the victim. Ames' memory of his robberies was remarkable. "I stole», he acknowledged, « a pair of silver buckles and a pair of turned pumps out of a pair of saddle bags at Leason's tavern in Waltham; the buckles were marked I.D.». Part of the purpose of the execution narrative was to inform victims of what happened to missing items. Ames' ability to identify what was stolen, where, and from whom makes his narrative read like a crime blotter. The inventory of loot taken from a Lexington home, for example, included a tankard, twelve tea-spoons, a pepper-box, and two pair of sugar tongs. Only rarely does he admit to a lapse in memory. "I have several times taken sundry articles off of lines, hedges, fences, bushes apple trees...», Ames confessed, «but I cannot recollect their owners ${ }^{40}$.

Ames' narrative provides a fascinating window into the life of a late eighteenthcentury petty criminal. Many of his robberies were opportunistic. He might find an unwatched basket of small coins at a baker's, an axe left carelessly in the back of a cart. When he took a horse, it was only in order to quickly slip out of town. It was a life marked by close escapes, sudden changes of dress - «I also stole... two coats and jackets with which I dressed myself when I came to Boston » - or even of name. «I then went», Ames wrote, «by the name of Isna Lawrence». Ames would sell his stolen goods to fences or peddle it himself. At times he must have missed a decent meal. While robbing a house at Marlborough, he searched for something to eat.

39 Levi Ames, The Life, Last Words, and Dying Speech of Levi Ames (Boston, 1773), p. 31. Boston Post-Boy, 25 September 1773. Although little work has been done on the connection between age and crime, Ames fits a pattern for youth offenders. See Davis (1971, p. 41-75) and Smith (1973, p. 149-161). Demographic data like that of Wrigley and Schofield (1981) would establish if the colonies, as well as England, was experiencing a rapid rise in the number of adolescents during this period.

40 Ames, Life, p. 31-33. Minute Book of the Superior Court of Judicature, 1773-1774, 30-31, Massachusetts Archives (Boston). 
Ames seems anything but threatening. Shunning armed robbery, he limited himself to small time pilfering and burglary. A number of his burglaries were committed on Sunday when there was less chance of encountering violence ${ }^{41}$.

In his fictive verse confession, Richardson was portrayed as acknowledging terrible crimes : perjury, adultery, incest, and murder. Yet the broadside poem justifying Ames' execution was hardly able to summon anything worse than bad habits. Death, portrayed as a skeleton, demanded the right to take Ames: «In adding guilt you still went on/I doubly claim you for my own/How often you the Sabbath broke !/God's name in vain you often took!/ A filthy drunkard you have been/And led your life with the unclean». Ames was not an heroic eighteenth-century criminal like Jack Shepherd or Jonathan Wild. No ballads would be written about Levi Ames. Often he was timid. If his execution narrative can be believed, Ames repaid certain of his victims. He refused to act as a fence for an associate because he «was afraid to do it ». When another thief tried to lure him into robbing the Governor's house, he declined. There were too many servants and Ames would have to go armed. «This I absolutely refuse because I never thought of murdering any man in the midst of all my... thieving ». Unlike Richardson, no one would accuse Ames of murder ${ }^{42}$.

Such strategic moves suggest that Ames had a hand in crafting his own execution narrative. Scholars have often envisioned such narratives as an instrument of the authorities for communicating a message of civil order. Nevertheless, felons commonly seized upon the genre as a means to tell their own story. Ames was no exception. His narrative must be read like a pardon petition. It self-servingly emphasized his best moments : repaying stolen goods, his stance against violence, and Ames' claim to repentence. "Though I lived such a wicked life», Ames wrote, «it was not without some severe checks. For after I had stolen, I have been so distressed at times, as to be obliged to go back and throw the stolen goods at the door, or into the yard that the owners might have them again». Shortly before his last arrest, Ames claimed he felt the burden of his criminal life: "I passed the gallows on Boston neck with some stolen goods under my arm when my conscience terribly smote me, and I thought I should surely die there, if I did not leave off this course of life». The execution narrative was a platform for Ames to make his final pleas. Richardson's mock dying confession was fabricated to use against his being pardoned. But Ames, who retained some control over his own narrative, reinvented his criminal self with the hope of a last minute reprieve ${ }^{43}$.

Ames was sentenced to death for a crime not too different from others in his past: a simple burglary. It was planned with a confederate, Joseph Attwood, who Ames claimed he met for the first time in Boston towards the end of August, 1773, shortly before attempting the burglary together. Here, again, was an example of Ames's selective memory. It appears that Ames and Attwood had broken into the house of a Lexington minister the previous spring ${ }^{44}$. Turning king's evidence against Ames, Attwood would later provide the testimony that would lead to Ames' capital

41 Ibid. For the social context of Ames' criminality, see: Kulikoff (1971). On the literary theme of wandering, see: Carnochan (1977). Linebaugh (1991) explores the relationship between criminal narrative and working class consciousness.

42 Ames, Speech of Death [broadside] and Ames, Life, p. 32-33.

43 Ames, Life, p. 34-5; Stillman (1773, p. 63-66).

44 Ames, Life, p. 33-34; Massachusetts Spy, 2 September 1773. 
conviction. Not surprisingly, then, Ames and Attwood had very different versions of their meeting. According to Attwood, Ames took him to dinner, plied him with wine, and told him that he had seen Martin Bicker return home from his auction house with a large sum of money. They walked from Market Square to the North End, and Ames tried to convince Attwood to join him in the theft. At the ship yards, the two slept a bit. Ames took a bottle from his pocket. While drinking still more, Attwood finally succumbed to Ames' coaxing ${ }^{45}$.

Ames told the story differently: "I was standing at a countryman's cart in the market at Boston, asking the price of a turkey; Attwood came up to me and we fell into conversation». Attwood and Ames walked up Beacon Hill. Attwood, Ames claimed, said he had no money and Ames offered him dinner. Ames convinced Attwood to fence some stolen goods. Then, in Ames' version of the story, it was Attwood who first suggested robbing Bicker's house: "he told me he knew of [someone]... who had a large sum of money by him, and if I would join him we would get it». Ames' description clearly attempts to shift the blame to Attwood. Tucked away in the midst of his execution narrative, it appears to be simply another straight-forward tale of crime. But Ames was doing more than unburdening his conscience before he dies. He had survived other convictions for burglary without suffering death. His narrative, must be seen as an extra-official species of testimony. A witness in his own defense, Ames followed the strategy of trying to create enough doubt about Attwood's evidence to prompt a pardon for himself ${ }^{46}$.

Such pleas stood squarely within a legal discourse. Nowhere was this clearer than in the description of the crime itself. "Having come to Mr. Bicker's house", stated Ames, « we found a front chamber window open; we pulled off our shoes, and Joseph Attwood with my assistance climbed up to the window and entered the house, and opened the doors for me; we then went together to the desk which we broke open with the chisels ». They stole forty pieces of silver, Spanish pieces of eight, and gold coins. Attwood's testimony was very different. He claimed that Ames supplied the instruments and climbed into a window while he waited outside and served merely as a lookout. Under the guise of making peace as he approached death, Ames pointedly underscored the fact that he insisted that Attwood had lied under oath. «I also forgive from my heart Joseph Attwood», Ames wrote in his narrative, "who swore on my trial that I entered the house of Mr. Bicker first, and let him in, when he knows in his conscience that he entered first and let me in ${ }^{47}$.

What Ames and Attwood disagreed about, of course, was the same issue as found in the Richardson case: the spatial configuration of the crime. Even as nonlawyers, they showed themselves aware of the legal definition of housebreaking. At issue was the actual entry into the house, which was the statutory characterization of the felony, not simply the theft of goods. While Ames blamed Attwood for the first illegal entry, Attwood denied entering at all. The money was found on both of them when captured. But it was windows and doors that once again proved significant as liminal structures. Although Ames pleaded not guilty, the court believed Attwood.

\footnotetext{
$45 \quad$ Massachusetts Spy, 9 September 1773.

46 Ames, Life, p.33. For other examples of Ames' earlier encounters with the criminal justice system, see: Minute Book of the Superior Court of Judicature, 1773-1774, 30-31, Massachusetts Archives.

47 Minute Book of the Superior Court of Judicature, 1773-1774, 118-19, Massachusetts Archives. Ames, Life, p. 33-34. Charters and General Laws, p. 406-407 and 668-669.
} 
On Friday, September 10th, 1773 Ames was sentenced to death for burglary. His execution was set for October 14th. Attwood, who was found guilty in part, would receive twenty stripes, and pay triple damages and costs. Unable to pay, Attwood was placed at Bicker's disposal for ten years ${ }^{48}$.

Ames hoped for a pardon. The Sunday before the execution, a Baptist minister cautioned: «All prospect of living longer than the time appointed is cut off. I hope you will not flatter yourself with a longer time». Yet Ames, not unreasonably, relied upon the capriciousness of the eighteenth-century criminal justice system with its frequent reprieves. Like the execution narrative, his behavior must be seen as a sort of legal document - an acted, rather than written, petition for a pardon. Ames tried to be a model prisoner. He expressed appreciation towards the people of Boston, ministers, and the jail keeper. "Levi Ames», wrote a Boston diarist, «attends public worship every Sabbath and infinite pains is taken by the ministers of the town to enlighten his mind in the knowledge of divine truth». As was the case with many condemned felons, Ames' life assumed a typological significance. Overlaid upon the criminal self of the execution biography was a protestant redemptive narrative $e^{49}$.

Once again, language played a critical role in inventing and reinventing the meaning of a criminal life. Richardson's language was provocative. According to a contemporary, he was «a rough speaker, and a passionate man... [who] insulted his opponent in gross terms ». It was not easy to be a supporter of the crown in revolutionary Boston. Richardson voiced the unspoken bitterness of his embattled patrons. On the other hand, Ames cannily adopted the idiom of deference towards those who held the power to pardon. Claiming to be contrite, Ames tried the classic gambit of felons : how could he face God's judgement without having the opportunity for a few more good deeds? «I feel I am lost», he told a minister. «I sometimes think that I am given over to destruction, and that there is no mercy for me. I am undone in soul and body. If I go to the place of execution as I am now, they must drag me like a bullock to the slaughter». Such comments contained a threat. The representational meaning of the execution could be remade into slaughter. Ames added the inevitable plea: "May I not have a little longer time than is now fixed?» Perhaps because of his penitent stance, perhaps because of the public outcry over the sentence of death, Ames was allowed a one week reprieve. Then, on October 21st, with an exceptionally large number of spectators present, Ames was hanged ${ }^{50}$.

The execution of Levi Ames turned into something of a cottage industry for Boston printers. During the course of the next month and a half, a flurry of poems, broadsides, dying speeches, and execution narratives and sermons would be published. What this collection of works reveals is the diversity of tropes that might be applied to a single criminal life. The execution sermons of ministers Samuel Stillman, Andrew Elliot, and Samuel Mather, not surprisingly, drew upon Protestant motifs. According to Stillman, Ames was Absalom, the beloved son who went astray. Eliot described Christ on the cross with thieves. For Mather, God was a physician prepared to heal Ames on his deathbed. Ames was promised mercy if he

48 Minute Book of the Superior Book of Judicature, 1773-1774, Massachusetts Archives, 118-119. Boston Post-Boy, 13 September 1773; Boston Gazette, 13 September 1773; Massachusetts Spy, 16 September 1773.

49

Stillman (1773, p.23-24). Ames, Life, p. 36; Boyle (1930, p. 367).

so Hewes (1985, p. 90); Stillman (1773, p. 57-60). Boston Gazette, 11 October 1773 and 28 October 1773. 
repented, judgement if he did not. «All heaven is purchas'd by His cross/ For such vile souls as thine», intoned an execution broadside full of religious imagery, «You leave this earth, it is no loss/If you in heaven may shine». Mixing Christian morals with civil authority, Stillman used the execution sermon as a forum to denounce deism, excessive drinking, gambling, and seducers who threaten the honor of women. Ames was a bit more prosaic when he listed his own last warnings. Parents and masters should discipline children. Beware, he cautioned, of bad women, cursing, and drunkeness. Stepping beyond the confines of Protestant execution sermon conventions, Ames offered some practical advice: « To keep your doors and widows shut on evenings, and secured well to prevent temptation. And by no means use small locks on the outside, one of which I have twisted when ease when tempted to steal. Also not to leave linen or clothes out at night». "Travelers », he added », I advise to secure their saddle bags, boots etc. in the chambers where they lodge».

The number and variety of execution texts about Ames seems astonishing. After all, Ames was not very different from many other petty criminals who plagued the colonies during the 1760 s and 1770 s. He did not perform any spectacular escapes, lead a gang of felons, or even commit murder. Why, then, was Ames the subject of so many works? The answer, once again, leads back to Ebenezer Richardson and the political context of revolutionary Boston. Sentencing Ames to death for burglary contrasted with the failure to punish Richardson for the more serious crime of murder. Richardson remained in prison for almost two years. London had sent one pardon, but uneasy about the technical details of the form and perhaps fearing unrest, Hutchinson requested another. By spring 1772, the Newgate pardon finally came. On March 12th, Richardson was secretly released from confinement ${ }^{51}$. Just a few months later, an inflammatory broadside entitled Theft and Murder conjured up the sight of Ames hanging on the scaffold while Richardson went free: "Come ye spectators, and behold/And view a doleful scene today/My tender fainting heart grows cold/And I am fill'd with sore dismay... Behold a man condemn'd to die/For stealing his neighbor's goods/But murder doth for vengeance cry/But where's the avenger of the blood».

Theft and Murder placed itself within the genre of execution poetics. Like many other examples of the genre, its frontpiece depicted the scene of execution. In stereotypic fashion, Ames was shown suspended from the gallows. Hovering above him stood a hangman on a ladder, while below a man on horseback appears to be issuing orders. Yet the message was radical: "'Tis a great crime to steal from $\mathrm{men} /$ And punishment deserves indeed/But murd'rers have released been/Who made our friends promiscuous bleed». The broadside incorporated Christian motifs. But these were more like those of Snider's martyrology than those found in Ames' execution sermons. As after Cain's murder of Abel, the victim's blood calls from the ground. The popular culture of execution narratives mingled with an attack on the fairness of English law. This was not a full American critique of the English criminal justice system - that would wait until the 1780s. Nor was the issue of class, which would become so important in the 1790s, yet raised in a truly conscious way. Nevertheless, Americans were clearly sensitive to the injustice of capital punish-

51 27 Massachusetts Archives, 210-211. PRO, «Domestic George III», IX: 84, 88 and «Domestic Entry Book, 1771-6», III:9 (4 September 1771); Hutchinson to Hillsborough, 15 May 1771, PRO, CO 5, 768/198-200; Massachusetts Spy, 12 March 1772. Oliver (1961, p. 87). 
ment for crimes against property at the same time that murder might be pardoned. "The life of man is more than gold/Or any other earthly good/But thieves are hang'd while murderers bold/ Are freed $»^{52}$.

"Must thieves who take men's good away/Be put to death», asked the anonymous author of this broadside, «while fierce blood hounds/Who do their fellow creatures slay/Are sav'd from death?» «This cruel sounds». Theft and Murder demanded a pardon for Ames. A newspaper article signed by Brutus compared England's robbery of the colonies with Ames' small scale pilfering. "He that riots on the plunder of his country deserves the gallows more than he that robs an individual ». Such patriot arguments would not go unanswered. Two other verse broadsides defended capital punishment for burglary. A burglar not only stole possessions, but peace of mind. An Address to the Inhabitants of Boston appealed to the fears of the city's hard-working citizens: «Industrious man o'ercome with sleep retires/Thinks to enjoy what he desires/The time that nature ordained for rest/When all the living may with sleep be blessed ». Yet even as the working man rests, burglars like Ames are plotting their thefts. "Then at this hour the felon strikes/When all in sleep are lost/But crafty thieves who live at others cost ${ }^{53}$.

With such arguments, the Address to the Inhabitants of Boston deflected the claim that English law was primarily concerned with the defense of property. Life, too, was at risk during a night time burglary. «Thro' fear of death he [the householder] dares not descend/Lest that the night in blood and slaughter end». The poem depicts the next morning when the victim, obviously distressed, surveys what has been stolen. It suggests that the only deterrent to such a crime was the example of capital punishment. The political debate, then, over English criminal law was couched in the vernacular form of execution literature. In a dying speech, attributed to Ames, the felon himself complained about the politicization of his fate: «babbling gossips» will tell his tale. Nevertheless, what is so striking in this case is the appropriation of a common felon's tale in the course of a wide-ranging legal debate about the character of criminal law. Like many offenders, Ames was described through a garden variety of tropes, such as Christianity's penitent thief or the prodigal son. But as placing blame spilled over from his singular case to a critique of the English legal system, Ames himself underwent a transfiguration. He became the thematic counterpoint to Richardson ${ }^{54}$.

In the Richardson affair, as well, Bostonians turned to the innovative use of vernacular legal culture. The court had declared that Richardson committed justifiable homicide. Pardoned by the crown, official legal process set him free. Richardson was, to borrow a phrase from Peter Oliver, found, «guiltless in law». Yet that was not the verdict of extra-official justice. The common people of Boston judged Richardson guilty of murder. An «infamous murderer», newspapers and broadsides

52 Theft and Murder, A Poem on the Execution of Levi Ames, Which is to be on Thursday, the 21st of October for Robbing the House of Mr. Martin Bicker, and was Convicted of Burglary (Boston, 1773) [broadside].

53 Theft and Murder [broadside]. Boston Gazette, 25 October 1773. Two works supporting Ames' execution are: An Address to the Inhabitants of Boston, Occasioned by the Execution of Levi Ames (Boston, 1773) [broadside]; Speech of Death [broadside].

54 Address to the Inhabitants [broadside]. The Dying Penitent; Or the Affecting Speech of Levi Ames, Taken from his own Mouth as Delivered by him at the Gaol in Boston in the Morning of His Execution (Boston, 1773) [broadside]. 
called Richardson. «The guilty, guilty murderer walks abroad ${ }^{55}$. Unable to hang Richardson in person, Bostonians at least chose to do so in their imagination. A broadside entitled The Humble Confession of Richardson imitated the conventions of the capital felon's dying speech. Along the upper border was a typical wood-cut illustration of the crime, depicting a street scene with Lillie's store clearly marked and the gathering crowd. A long, smoking rifle barrel extends from a second story window. It began with the formulaic prologue of the last confession: «Injured Boston now awake/While I a true confession make/Of my notorious sins and guilt/As well as the harmless blood I've spilt». In this fictive dying speech, Richardson admits to having been both an adulterer and an informer. Yet these are small crimes compared to murder. «But what's all that to this last crime/In sending Seider out of time !/This cuts my heart, this frights me most/O help me, Lord, I see his ghost». From the last lines of the confession, it appears that the broadside was used with an effigy. Presumably, the effigy would be hanged with all the ritual and pageantry of official justice. «And now my injur'd friends/Since I can make you no amends », the Richardson figure urged, «Here is my body you may take ${ }^{56}$.

While the stuffed Richardson figure may have been executed, the real Richardson upon receiving his pardon from London was quickly spirited out of town. Here, too, Bostonians drew upon the forms of popular legal culture. They drafted a mock advertisement for him of the sort used for wanted criminals. "The infamous Ebenezer Richardson», its headline blazoned, «convicted of perjury \& murder» was rumored to have fled to Philadelphia. «Richardson rioting in the spoils of his country, lurks about the wharves of this city, seeking an opportunity to distress the trade of Philadelphia and enslave America». Like any proper notice for an outlaw, it included a full description: «The above Richardson appears to be a man of 46 years of age is about five feet four or five inches high, pretty thick and broad across the shoulders, has a very ill countenance and down look, pits-burnt cut wig, and a blue surtout coat with metal buttons ${ }^{57}$.

No court reporter recorded Richardson's trial. Yet literary and artistic representations, including theater, prints, and poetry, meant that they entered into popular memory. More than a year after the riot in front of Richardson's house, Paul Revere constructed a transparent painting not of the scene itself, but of Snider's ghost in the same pose as when he was wounded. A couplet underneath read: «Seider's [sic] pale ghost fresh bleeding stands/And vengeance for his death demands ». In some ways, the specter of the case was more important than either Richardson or Snider themselves. «Young Seider's blood from th' op'ning ground cries justice, justice here thee sound ». The infamous murderer Richardson was released, went a demand for remembrance published in 1772, «tell this in Britain, publish it in Ireland, may America remember it forever".

These small pieces echoed any number of Biblical commonplaces. In them lies a code which can be deciphered when juxtaposed to their Biblical source. «Justice, justice», any literate colonial would know, referred to the passage in Deuteronomy

55 Oliver (1961, p. 86). On Richardson's guilt, see for example: Massachusetts Spy, 2 May 1771, 12 March 1772, and 14 May 1772; Boston Gazette, 10 February 1772. A Monumental Inscription on the Fifth of March, Together with a few Lines on the Englargement of Ebenzer Richardson (Boston, 177?) [broadside]. 
which attacks bribing judges, a probable reference to the judicial salary dispute. The Biblical quote «justice, justice pursue» predicates living in the land of Israel upon following basic principles of justice. What this evokes, of course, is a Puritan historical conceit: Massachusetts settlers are Israelites, America the promised land. «Tell this in Britain, publish it in Ireland » must be read as a text against David's eulogy of Saul and Jonathan who were murdered by the Philistines. David demanded «Tell it not in Gath, Do not proclaim it in the streets of Ashkelon ». Here the English take the pose of the enemies of Israel, the Philistines. But in this case, unlike the Biblical passage, the anonymous colonial polemicist wants the English/Philistines to admit their own crimes. Finally, the most potent recurring Biblical trope was that of Cain and Abel. Cain and Abel were brothers, Richardson and Snider both countrymen. Snyder's blood, like Abel's cries from the opening ground. The blood of Snider «crieth out for vengeance like the blood of righteous Abel». Richardson borrows Cain's visage, «a very ill countenance and down look». The murdered Abel's marking is blood. As with Cain, Richardson was not executed. Instead, he was marked. «I believe», wrote a colonial, Richardson is «suffering Cain's punishment». For Cain and for Richardson, the marking was exclusion, exile, and memory ${ }^{58}$.

Richardson and Ames were not the only ones tried on the streets of Boston. Having pardoned a murderer and chosen to execute a petty thief, the court was judged as well. Massachusetts Superior Court had been unpopular for much of the last decade. In 1761-2, the court sanctioned writs of assistance, broadly defined search warrants employed by customs officers. It further alienated the population through supporting the Stamp Act and adjourning the court when faced with popular pressure. The people of Boston, Hutchinson wrote in 1765, « will oblige all judges to observe their orders or quit their places $»^{59}$. Alarmed by a court that actively buttressed English authority, the legislature curbed judicial salaries. Towards the end of the 1760 s, the crown adopted a strategy of trying to shift influence over the judiciary from the legislature to the executive. Judicial salaries were now paid by the royal authorities and appointments to the bench were based largely upon political considerations. At the beginning of 1772, the resignation of two justices, John Cushing and Benjamin Lynde, created vacancies on the Superior Court. Peter Oliver was named chief justice and Nathanial Ropes became an associate justice.

Both Oliver and Ropes were considered loyal supporters of the royal government. Oliver's brother, Andrew, was a stamp distributor. The same year as his appointment to the court, Oliver participated in the unpopular investigation into the destruction of the Gaspee, a navy schooner assigned to stem smuggling in Narragansett Bay. Demonstrating firm commitment to London, Ropes lost his Council seat in 1769. Yet it was the issue of the judges' salaries that led to massive agitation against the Superior Court. Bostonians accused justices of being blinded by bribery and beholden to the Crown. «Base and mercenary wretches», wrote one newspaper, «fill the bench of justice, who will throw off all the restraint of law and give judgement according to the direction of their masters $»^{60}$. As early as 1770 , a

\footnotetext{
58 Massachusetts Spy, 7 March 1771 and 12 March 1772. Virginia Gazette, 5 April 1770. Boston Gazette, 1 November 1773. Massachusetts Spy, 30 January 1772.

59 Hutchinson, 26 Massachusetts Archives, 27 December 1765.

60 Boston Gazette, 31 August 1772.
} 
placard was posted on the door of the town hall attacking the justices of the Superior Court. During the summer of 1773 , barely a few months before Ames was hanged for burglary, the Massachusetts House of Assembly demanded that judges refuse the Crown grant or face impeachment. Boston mobs intimidated justices into signing a renunciation. Only Peter Oliver defied these threats. Impeachment proceedings were initiated and there was a movement to boycott jury duty on a court that many felt was no longer legitimate. Fearing that he might be attacked, Oliver absented himself from the bench. Without Oliver, the court failed to fulfill its duties ${ }^{61}$.

Such popular disaffection with the judiciary, then, must be seen as the context for the debate over the contrasting fates of Richardson and Ames. The presiding judge for both trials was Peter Oliver. Not surprisingly, Bostonians echoed the tone of the judicial salary dispute and argued that the outcome of Richardson's trial was determined by politics. «Political motives », it was suggested, « influenced a delay in judgement and execution of this criminal». Quincy warned that if "political views» should ever shape the decisions of judges, « who have the lives, liberty and property of us all in their power, society is worse than a state of nature». Mary Otis Warren's satiric drama on the Hutchinson administration, The Adulateur, again raised the notion of political corruption as the basis for any pending pardon of Richardson: «You know who fills that sacred bench... mere creatures of the tyrant [Hutchinson]. Depend upon it, they'll vilely wrest the law, and save the villain [Richardson] - yes depend upon it». The term "wrest» clearly alludes both to its meaning as altering interpretation and to the image of seizing the law - away from the people? - and taking posession of it by force. «Should he be brought before that bribed tribunal, they'll plead his case, and save the murderer's life». Following the classic literary inversion of the justice as criminal, Warren adds «I've seen such crimes by ermined wretches as would have shock'd a century ${ }^{62}$.

More than any other legal proceedings, criminal justice should be the least affected by politics. The protection of citizens from criminals, after all, was considered by eighteenth-century legal theorists as fundamental for every society. Yet according to contemporaries, precisely because Richardson's case was criminal it established the right of the people to judge the legal system. "When a breach of criminal law is made, it is the public who are injured by the infraction... shall the injured not call for redress?». Bostonians portrayed Richardson as a criminal offender shielded for political reasons. By pardoning a murderer, the court sanctioned the greatest of felonies. The Superior Court, declared a town meeting at Sandwich, has been «rendered dependent on those who rob and murder us». Law would lose its legitimacy, if people «perceive the destruction of their fellow citizens is treated as a slight thing and blood, innocent blood, crimsoning their city ${ }^{63}$.

As with his trial, Richardson's confinement and pardon prompted legal issues that overflowed from the courtroom to the popular press. Was it right, for example,

61 Massachusetts Spy, 13-17 December 1770. Boston Evening Post, 5 July 1773. House of Representatives, Impeachment of Peter Oliver, 12 February 1774, Miscellaneous Bound Manuscripts 1765-1776, Massachusetts Historical Society. «Refusal of Certain Gentlemen to Serve as Grand Jurors», (30 August 1774) in Niles, (1822, p. 319). Smith (1978, p. 202-230); Black (1985); Cushing (1965, p. 168-186); Russell (1980, p. 95-149).

62 Boston Gazette, 10 February 1772. Warren, Adulateur, p. 11-13 and 30.

63 Sandwich, Massachusetts town meeting, 17 March 1773 reported in the Massachusetts Spy, 18 March 1773; Boston Gazette, 10 February 1772. Massachusetts Spy, 5 March 1772. 
that Richardson should be held in prison so long without being either executed or released as innocent? What law justified this breach of habeas corpus. Many Bostonians, of course, wanted Richardson hanged, not freed. But Richardson's extended confinement, a legal netherland, provoked questions about the role of prisons. Prior to the rise of penitentiaries in the $1780 \mathrm{~s}$, their use as an instrument of punishment remained controversial. One newspaper article adopted the traditional stance towards prisons as simply way stations and chided the criminal justice system for letting Richardson languish in jail: «A jail was never intended for punishment, but only to hold the debtor till he fulfilled his voluntary contracts; the suspected till his offence could be conveniently ascertained; and the convicted till speedy justice could be executed ». The administration of justice, it warned, retains its integrity by being swift and without hesitation. Imprisoning Richardson only to await a pardon, shows a "secret cunning» and such conduct in justices is «base, odious, and execrable $»^{64}$.

«Ebenezer Richardson remains alive», complained one Bostonian, «to insult and defy the avengers of blood to obtain of him the least satisfactions. And this unaccountable political phenomenon is solved only by the extension of the ancient notion of benefit of clergy $"{ }^{65}$. The New England colonies had long been troubled by the idea of benefit of clergy. It seemed obscure, an arbitrary form of pardon, and overly Catholic. Benefit of clergy traced its origins from the right of clerics to the separate jurisdiction of ecclesiastical courts. As the use of separate courts shifted to the practice of trying clergymen in the same court as laymen, clerics were provided with a special privilege, benefit of clergy, which protected them from capital punishment. The classic test for identifying a cleric was the ability to read. By the fourteenth century, benefit of clergy was extended to anyone demonstrating minimal literacy. Ultimately, it came to be used as a general form of pardon that provided a way for courts to temper the many capital statutes found in English criminal codes. «An unreasonable exemption of popish ecclesiastics», Blackstone claimed, was gradually transformed «into a merciful mitigation of the general law with respect to capital punishment $\gg$.

Yet patriot lawyers increasingly considered benefit of clergy a remnant of cannon and feudal forms that England imposed upon the colonies. It only entered Massachusetts codes in 1686 during the much hated anglicizing governorship of Edmund Andros. After the Revolution, Massachusetts law would quickly move to dismantle benefit of clergy as, in the words of the 1785 repealing act, «originally founded in superstition and injustice ${ }^{67}$. A verse broadside mocked Richardson's pardon by benefit of clergy: «Oh! Wretched man! The monster of the times/You were not hung by 'reason of old lines'/Old lines thrown by/'twas then we were in hopes/That you would soon be hung with new made ropes ". Once again, the counterpoint of Ames' fate must have underscored the arbitrariness of benefit of clergy. Just a few years before Ames was convicted, in 1770, a new Massachusetts statute removed burglary as a clergyable offence. Enacted in the midst of a crime wave and

64 Boston Gazette, 10 February 1772. Quincy authorship. Hutchinson remark about prison.

65 Boston Gazette, April 11771.

66 Blackstone (1979, IV, p. 358-364). Beattie (1986, p. 141-148). Dalzell (1955, p. 169-181); Cross (1928, p. 154-181).

67 Massachusetts Statutes, 11 March 1785. 
replacing a more mild 1715 law, it was cast in the model of England's harsher criminal code. «However rigorously the laws may be executed against indifferent offenders », went the complaint, «it seems to be laid down as a fixed maxim that no murderer shall suffer during the present reign, if he has even the remotest connection with the servants of the king $»$. Bostonians must have marveled that a murderer could be pardoned with benefit of clergy while that loophole was now closed to a burglar like Ames ${ }^{68}$.

There was yet another contradiction between the fate of Richardson and Ames that would have troubled Bostonians. According to the English murder act of 1752, murderers, not any other felons, would suffer dissection « to add some further terror and peculiar mark of infamy... to the punishment of death». The act was, in fact, intended to distinguish lesser capital crimes such as burglary from murder. No statutory basis yet existed for dissection as a form of punishment in the colonies, that innovation would come with a flurry of laws in the late 1780 s and early 1790 s, but colonial Americans were well aware of its punitive role. In the streets of Boston Richardson was judged guilty of murder. He nevertheless escaped not simply the gallows, but the surgeons as well. Yet Ames, though simply convicted of housebreaking, was threatened by dissection.

Historians have shown how much eighteenth-century Anglo-Americans feared the surgeons. Not just at London's Tyburn, where the common people frequently rioted to retrieve the bodies of hanged criminals, but also in America dissection was seen as a worse fate than the gallows. During a 1771 riot at Worcester, an angry crowd rescued the corpse of a hanged felon from dissection. Ames, too, appeared to share that fear. Probably one reason for the special relationship formed between Ames and the minister who cared for him as a condemned prisoner, Rev. Samuel Stillman, was that Ames hoped Stillman would protect him from the surgeons. Three parties contended for Ames' body after the execution: established doctors, including James Lloyd and John Clarke, under the direction of Dr. John Jefferies, a coterie of young medical students at Harvard, and a rescue party employed by Stillman. Hutchinson, in fact, was ready to order the corpse handed over to Jefferies when Stillman intervened. Much to the disappointment of the competing anatomists, Stillman secretly buried Ames at Dorcester Point. Nevertheless, Bostonians must have been struck by the irony of how different were the fates of Richardson and Ames. Hutchinson was willing to sanction Ames' dismemberment ${ }^{69}$.

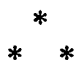

What lessons, then, do we learn from these two remarkable cases? Placing blame meant not only finding an individual felon culpable, but a critical reading of the legal apparatus-and its English constitutional underpinnings-as well. It seems

68 On the Enlargement of Ebenezer Richardson Convicted of Murder [broadside]. "An Act for Preventing and Punishing Burglary, and for repealing of an act entitled, An Act Against Burglary ", $10 \mathrm{Geo}$. III (1770) and 1 Geo. I (1715) in Charter and General Laws, p. 406 and 668-669. Boston Gazette, 9 July 1770 and Massachusetts Spy, 21 October 1771. The reference to "new made ropes " is a pun on Justice Nathaniel Ropes who was recently appointed to the Superior Court.

69 «An Act for the Better Preventing the Horrid Crime of Murder» (25 Geo. II, c. 37, 1752). Linebaugh (1975) and Wilf (1989). Mathews (1916-1917, p. 273-290). 
clear that the street, as much as the courtroom, was the locus of this interpretive understanding of criminal and constitutional narratives. The debate over the justice of Richardson's pardon and Ames' hanging could be found in newspapers, political broadsides, and such productions of vernacular legal culture as execution sermons, dying speeches, and the mock executions of effigies. Popular culture, not high constitutionalism, mediated between politics and official law. Eighteenth-century Bostonians demonstrated their ability to grasp complex legal doctrine: criminal intent, distinctions between murder and manslaughter, the role of juries in judging fact and law, the weighing of appropriate punishment for theft, and the place of incarceration or dissection as an instrument of punishment. More strikingly, the transformation of these cases show how adept colonial radicals were at the manipulation of legal symbols. Historians often have claimed that rebellion is antinomian, a rejection of the rule of laws. But just the opposite occurred in revolutionary Boston. The common people domesticated legal discourse. Precisely because legal process, and especially criminal law, was invested with a new-found political meaning, Americans would be able to construct a different understanding of punishment in the late 1770 s and 1780 s, radically rejecting sanguinary punishment as a norm.

Nothing better illustrates the popular appropriation of punishment in these cases than two small advertisements appearing in colonial papers. Barely a few lines each, these notices appear insignificant. But they demonstrate how radically the topography of justice had shifted. Levi Ames' confessions, one advertisement read, are "available in the shop across from the courthouse». Separated only by a street, the printing press, with its vernacular executions narratives, and the courthouse marked alternative seats of legal authority. Similarly, a mock advertisement identified Richardson as a wanted man. It called on Philadelphians to «produce him tarred and feathered at the coffee house, there to expiate his sins against his country by a public recantation ». This notice embodied what must be understood as a demand for Richardson's retrial. But there were significant differences. The purpose of the new trial would be retribution. Punishment would proceed his appearance and Richardson would not be allowed to escape unchastised. This time the public confession would be crafted by Richardson himself, not fabricated as a piece of popular culture. Most importantly, the coffee house replaced the courthouse as the place of justice ${ }^{70}$.

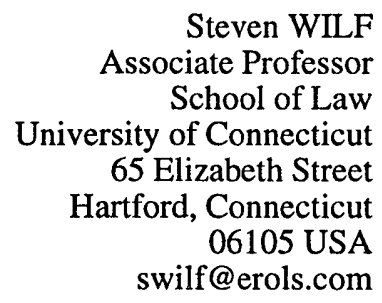

70 Boston Gazette, 25 October 1770 and 1 November 1773. 


\section{References}

Adams, C.F., (Ed.), The Works of John Adams, 10 vols., Boston, Charles E.; Little and James Brown, 1851.

Adams, J., Diary and Autobiography of John Adams (Edidted by L.H. Butterfield), 4 vols, Cambridge, Harvard University, 1962.

Adams, J., Legal Papers of John Adams, 3 vols., (Eds. L. Kinvin Wroth and H. B. Zobel), Cambridge, Harvard University Press, 1965.

Bauman, R., Let Your Words be Few: Symbolism of Speaking and Silence Among Seventeenth-Century Quakers, Cambridge, Cambridge University Press, 1983.

Beattie, J.M., Crime and the Courts in England 1660-1800, Princeton, Princeton University Press, 1986.

Black, B.A., Massachusetts and the judges: Judicial independence in perspective, Law and History Review, 1985, 3, p. 101-162.

Blackstone, W., Commentaries on the Laws of England, 4 vols., (Ed. Stanley N. Katz), Chicago, University of Chicago Press, 1979.

Boyle, J., Boyle's journal of occurrences in Boston, New England Historical and Geneological Register, 1930,84 , p. 367.

Brewer, J., The Wilkites and the law, 1763-1774: A study of radical notions of governance, in Brewer, J., Styles, J., (Eds.), An Ungovernable People: The English and their Law in the Seventeenth and Eighteenth Centuries, New Brunswick, Rutgers University Press, 1980.

Carnochan, W.B., Confinement and Flight: And Essay on English Literature of the Eighteenth Century, Berkeley, University of California Press, 1977.

Cohen, D.A., A fellowship of thieves: Property criminals in eighteenth-century Massachusetts, Journal of Social History, 1988, 22, p. 65-92.

Cross, A.L., Benefit of clergy in american criminal law, MAHSP, 1928, 61, p. 154-181.

Cushing, J.D., The judiciary and public opinion in revolutionary Massachusetts in Billings, G.A., (Ed.), Law and Authority in Colonial America, Barre, Mass, Barre Publishers, 1965.

Dalzell, G.W., Benefit of Clergy in America and Related Matters, Winston-Salem, John F. Blair, 1955.

Davis, N.Z., The reasons of misrule: Youth groups and charivaris in sixteenth-century France, Past and Present, 1971, 50, p. 41-75.

Davis, N.Z., Fiction in the Archives: Pardon Tales and their Tellers in Sixteenth-Century France, Stanford, Stanford University Press, 1987.

Dickerson, O.M., The Navigation Acts and the American Revolution, Philadelphia, University of Pennsylvania Press, 1951

Dickinson, A.T., Logue, K., The porteus riot: A study of the breakdown of law and order in Edinburgh, 1736-1737, Journal of the Scottish Labor History Society, 1976, p. 21-40.

Eakin, J., Fictions in Autobiography: Studies in the Art of Self-Invention, Princeton, Princeton University Press, 1985.

Fowle, E.C., Descendants of George Fowle (1610/11-1682), of Charlestown, Massachusetts, Roberts, G.B. and Thompson, N.D., Boston, New England Historic and Genealogical Society, 1990.

Green, T.A., The jury and the english law of homicide 1200-1600, Michigan Law Review, 1976, 74 p. 413-499.

Green, T.A., Verdict According to Conscience: Perspectives on the English Criminal Jury 1200-1800, Chicago, University of Chicago Press, 1985.

Green, T.A., A retrospective on the criminal trial jury, 1200-1800, in Cockburn, J.S., Green, T.A., (Eds.), Twelve Good Men and True: The Criminal Trial Jury in England, 1200-1800, Princeton, Princeton University Press, 1988, p. 358-400.

Greenberg, D., Crime and Law Enforcement in New York 1691-1776, Ithaca, Cornell University Press, 1976.

Hay, D., Property, authority, and the criminal law, in Hay, D., Linebaugh, P., Rule, J.G., Thompson, E.P., Winslow, C., (Eds.), Albion's Fatal Tree: Crime and Society in Eighteenth-Century England, New York, Pantheon Books, 1975, p. 17-64. 
Hay, D., The class composition of the palladium of liberty: trial jurors in the eighteenth century, in Cockburn, S., Green, T.A., Twelve Good Men and True: The_Criminal Trial Jury in England 12001800, Princeton, Princeton University Press, 1988, p. 305-357.

Hewes, G.R.T., Traits of the Tea Party, Being a Memoir of George R.T. Hugues (Edited by a Bostonian [Benjamin Bussey Thatcher]), New York, Harper \& Brothers, 1835.

Heyrman, C.L., Commerce and Culture: The Maritime Communities of Colonial Massachusetts 16901750, New York, W.W. Norton, 1984.

Howell, T.B., A Complete Collection of State Trials, London, T.C. Hansard, 1816-28, 34 vols.

Isaac, R., The transformation of Virginia 1740-1790, Chapel Hill, University of North Carolina, 1982.

Johnson, E.D., Woburn Records of Births, Deaths, and Marriages 1640-1873, Woburn, Andrews, Cutler \& Co., 1890.

Kaye, J.M., The early history of murder and manslaughter, Law Quarterly Review, (1967, 83, p. 365-394 and 569-601).

Krauss, S.D., An inquiry into the right of criminal juries to determine the law in colonial America, The Journal of Criminal Law and Criminology, 1998, p.111-214.

Kulikoff, A., The progress of inequality in revolutionary Boston, William and Mary Quarterly,1971, 28, p. 375-412.

Laden, M.-P., Self-Imitation in the eighteenth-century novel, Princeton, Princeton University Press, 1987.

Langbein, J.H., Shaping the eighteenth-century criminal trial: The view from the ryder sources, Chicago Law Review, 1983, 50, p. 1-136.

Lewis, J., The republican wife: Virtue and seduction in the early republic, William and Mary Quarterly, 1988,45, p. 391-425.

Linebaugh, P., The tyburn riot against the surgeons, in Hay, D., Linebaugh, P., Rule, J.G., Thompson, E.P., Winslow, C., (Eds.), Albion's Fatal Tree: Crime and Society in Eighteenth-Century England, New York, Pantheon Press, 1975.

Linebaugh,P., The ordinary of Newgate and his Account, in Cockburn, J.S. (Ed.), Crime in England 15001800, Princeton, Princeton University Press, 1977.

Linebaugh, P., The London Hanged: Crime and Civil Society in the Eighteenth Century, Cambridge, Cambridge University Press, 1991.

Lynde, B., jr., Diaries of Benjamin Lynde and Benjamin Lynde, jr., Boston, private printing, 1880.

Mann, B.H., Neighbors and Strangers: Law and Community in Early Connecticut, Chapel Hill, University of North Carolina Press, 1987.

Mathews, A., Early autopsies and anatomical lectures, Publications of the Colonial Society of Massachusetts, Transactions, 1916-1917, p. 273-290.

Mitnick, M., From Nneighbor-witness to judge of proofs: The transformation of the english civil juror, American Journal of Legal History, 1988, 32, p. 201-235.

Morris, R., A Letter to Sir Richard Aston...and Some Thoughts on the Modern Doctrine of Libels, London, 1770.

Murrin, J.M., Anglicizing an American Colony: The Transformation of Provincial Massachusetts, (Ph.D. diss.), Yale University, 1966.

Nelson, W., Americanization of the Common Law: The Impact of Legal Change on Massachusetts Society 1760-1830, Cambridge, Harvard University Press, 1975.

Nelson, W.E., The eighteenth-century background of John Marshall's constitutional jurisprudence, Michigan Law Review, 1978, p. 893-960.

Niles, H., Principles and Acts of the American Revolution, Baltimore, 1822.

Nobles, G., Divisions throughout the Whole: Politics and Society in Hampshire County, Massachusetts 1740-1775, Cambridge, Cambridge University Press, 1983.

Oliver, P., Origin and Progress of the American Rebellion, (edited by Adair, D., and Schutz, J.), Stanford, Stanford University Press, 1961 [1781].

Quincy, J., Reports Argued and Adjudged in the Superior Court of Judicature of the Province of Massachusetts Bay Between 1761 and 1772, Boston, Little, Brown, and Company, 1865. 
Radzinowicz, L., A History of Criminal Law and its Administration from 1750: The Movement for Reform 1750-1833, 4 vols, New York, Macmillan Company, 1948.

Roeber, A.G., Faithful Magistrates and Republican Lawyers: Creators of Virginia Legal Culture 16801810, Chapel Hill, University of North Carolina Press, 1981.

Rosen, L., The Anthropology of Justice: Law as Culture in Islamic Society, Cambridge, Cambridge University Press, 1989.

Rosenberg, N.L., Protecting the Best Men: An Interpretive History of the Law of Libel, Chapel Hill, University of North Carolina Press, 1986.

Rous, G., A Letter to the Jurors of Great Britain, London, 1771.

Russell, P.E., His Majesty's Judges: The Superior Court of Massachusetts, 1750-1774, (Ph.D. diss.), University of Michigan, 1980.

Schlesinger, A.M., The Colonial Merchants and the American Revolution 1763-1776, New York, Frederick Ungar, 1957.

Sewall, S., The History of Woburn, Boston, Wiggin and Luntt, 1868.

Smith, M.H., The London apprentices as seventeenth-century adolescents, Past and Present, 1973, 61, p. $149-161$.

Sharpe, S.R., Last dying speeches: Religion, ideology, and public executions in seventeenth-century England, Past and Present,1985, 107, p. 144-167.

Smith, S.R., The Writs of Assistance Case, Berkeley, University of California Press, 1978.

Stillman, S., Two Sermons...Delivered the Lord's-Day Before the Execution of Levi Ames, who was Executed at Boston, Thursday October 21, 1773 for Burglary, Boston, 1773.

Stimson, S.C., The American Revolution in the Law: Anglo-American Jurisprudence before John Marshall, Princeton, Princeton University Press, 1990).

Towers, J., An Enquiry into the Question whether Juries are, or are not Judges of Law as well as of Fact, London, 1764.

Ulrich, L.T., A Midwife's Tale: The Life of Martha Ballard, Based Upon_her Diary, 1785-1812, New York, Alfred A. Knopf, 1990.

Vinton, J.A., The Richardson Memorial, Comprising a Full History and Genealogy of the Three Brothers Ezekiel, Samuel, and Thomas Richardson, Portland, Maine, Brown Thurston, 1876.

Wilf, S., Anatomy and punishment in late eighteenth-century New York, Journal of Social History, 1989, 22, p. 507-530.

Wilf, S., Imagining Justice: Aesthetics and public executions in late eighteenth-century England, Yale Journal of Law \& the Humanities, 1993, p. 51-78.

Wood, G., Conspiracy and the paranoid style: causality and deceit in the eighteenth century, William and Mary Quarterly, 1982, 39, p. 401-444.

Wrigley, E.A., Schofield, R.S., The Population History of England 1541-1971: A Reconstruction, London, Edward Arnold, 1981. 